\title{
Platelet Rich Fibrin Versus Collagen Membrane Combined with Beta Tri Calcium Phosphate/Collagen for Treatment of Dehiscence around Immediately Placed Implants Clinical and Radiographic Comparative Study
}

\author{
Mahmoud A. Mizar ${ }^{* 1}$, Khalid S . Hassan ${ }^{1}$, Ahmed K. Mohammed ${ }^{1}$, Ibrahim M. Mwafy ${ }^{1}$
}

Codex : 10/2021/10

Aadj@azhar.edu.eg

\section{KEYWORDS}

Platelet Rich Fibrin,

Collagen Membrane,

Beta Tri Calcium Phosphate/Collagen,

Dehiscence, immediate implant

1. Department of Oral medicine, Periodontology, Diagnosis and Oral radiology, Faculty of Dental Medicine, (Assiut, boys), Al-Azhar University, Egypt.

* Corresponding Author e-mail: MamoudMizar.46@azhar.edu.eg

\section{ABSTRACT}

Aim: This study designed to compare clinically and radiographically between Platelet Rich Fibrin (PRF) membrane and collagen membranes in combination with Beta tri calcium phosphate $\beta \mathrm{TCP} /$ collagen in treatment of dehiscence around immediately placed dental implant. Subjects and methods: This study was performed on 20 sites from 20 patients who each received an immediate implant for a single tooth replacement at a maxillary anterior or premolar site. Patients were divided into two groups according to the augmented materials used. One group received an immediate implant and filling of defects using Beta Tri Calcium Phosphate/Collagen bone graft covered with PRF membrane. The other group received an immediate implant and filling of defects with Beta Tri Calcium Phosphate/Collagen covered with collagen membrane. Cone beam computed tomography (CBCT) was taken before placement, and at 6 and 12 months post-surgery. Results: Both treatment procedures resulted in significant improvements for the primary outcome regarding bone fill as well as thickness and height of buccal bone. In addition, statistically significant differences were found in the buccal bone height, thickness and bone density for the group treated with Beta Tri Calcium Phosphate/Collagen combined with collagen membrane compared with sites treated with Beta Tri Calcium Phosphate/Collagen combined with PRF membrane .Conclusion: Beta Tri Calcium Phosphate/Collagen combined with collagen membrane is significantly superior than Beta Tri Calcium Phosphate/Collagen combined with PRF membrane in treatment of buccal bone dehiscence during immedite implant placement

\section{INTRODUCTION}

Implant therapy is widely regarded as a reliable treatment option to replace missing teeth, for both function and esthetics. ${ }^{1,2}$

Original implant treatment guidelines advocated 3-6 months waiting period after tooth extraction to allow for soft and hard tissue healing before placing an implant, which was followed by an additional 
3-6 months load-free period after implant placement to achieve osseointegration. ${ }^{3}$

Immediate implant placement (IIP) had been a popular treatment concept for patients as well as for clinicians since it reduces the number of surgical interventions and the total treatment time. ${ }^{4}$

During immediate implant placement there are some bony defects may occur such fenesteration and dehiscence. ${ }^{5}$

Dehiscence is considered as one of the major bony defects, and defined as a V-shaped defect located along the alveolar bone margin (BM) toward the apex, and is more common in buccal side of the tooth. ${ }^{5}$

The etiology of dehiscences can be attributed to many factors, such as tooth ectopia, root projection, periodontal inflammation, frenum attachments, root vertical fracture and patient habits. ${ }^{6}$

A variety of surgical procedures have been utilized to improve buccal bone thickness for the placement of implants involving various grafting material techniques. Among these techniques, guided bone regeneration (GBR). GBR is used to treat fenestration and dehiscence around dental implants.

Different bone substitutes have been used for treatment dehiscence around dental implants, such as autograft, allografts, xenografts and alloplastic materials. Autograft is considered the gold standard for bone augmentation because of their properties. However, donor site morbidity, potential resorption, size mismatch and an inadequate volume of graft material limit the use of autogenous grafts. ${ }^{8,9}$

Beta tricalcium phosphate/collagen $\beta-\mathrm{TCP} / \mathrm{col}$ is a biocompatible and bioresorbable material with properties similar to the inorganic phase of bone and resulted in formation of newly formed bone. ${ }^{10}$

To overcome problems associated with GBR procedure, barrier membranes are frequently used to stabilize graft materials and to serve as a separating barrier in GBR therapy. ${ }^{11}$

Collagen membrane is widely used for the GBR procedure. Numerous clinical studies with these membranes have demonstrated their clinical usefulness. $^{12}$

In the field of dental implants, PRF has been utilized as a clot, mixed with a bone graft, or as a membrane in an effort to enhance and accelerate tissue healing.

A platelet-rich fibrin (PRF) membrane is a readily available and inexpensive biomaterial that is beneficial in implant dentistry and periodontal plastic surgical procedures. ${ }^{13}$

\section{AIM OF THE STUDY}

The present study was designed to compare clinically and radiographically between Platelet Rich Fibrin (PRF) membrane and collagen membrane in combination with Beta tri calcium phosphate $\beta$-TCP/collagen in treatment of dehiscence around immediately placed dental implant.

\section{PATIENTS AND METHODS}

\section{Study setting and population}

The present randomized controlled clinical study was carried out on twenty patients of both sex (6 males and 14 females, aged 22 to 45 years; mean age: $32.25 \pm 3.15$ years)

All patients were selected from those attending at the out-patient clinic, Oral Medicine and Periodontology Department, Faculty of Dental Medicine, Al-Azhar University, Assiut Branch.

The selected patients were planned to receive an immediate implant as a replacement of a hopeless maxillary teeth (midfacial vertical root fracture, endodontic failure and non-restorable caries and periodontally affected teeth) with a dehiscence of 
the labial osseous plate in the anterior teeth and premolars of the maxilla (single rooted tooth).

The present randomized controlled clinical study was conducted in accordance with the revised World Medical Association Declaration of Helsinki and was approved by the research ethics committee of the Faculty of Dental Medicine, Al-Azhar University, Assiut.

Written informed consent was obtained from all patients

\section{Inclusion and exclusion criteria for selection:}

1. Systemically healthy patients were selected.

2. The implant sites had sufficient vertical interarch space to accommodate the restorative components.

3. Patients with parafunctional, occlusal habit, smokers and bad oral hygiene were excluded.

\section{Patients grouping and randomization}

Patients were classified randomly into the following equal two groups using flipping coins.

Group I: Ten patients ( 3 males and 7 females ranged in age (between 22 and 40 years old with a mean age $31.5 \pm 2.7$ years) were received immediate dental implant combined with Beta tri calcium phosphate/collagen $\beta$-TCP/coll (RTR) ${ }^{1}$ covered with Platelet Rich Fibrin membrane.

Group II: Ten patients ( 3 males and 7 female ranged in age (between 25 and 45 years old with a mean age $33 \pm 3.6$ years) were received immediate dental implant combined with Beta tri calcium phosphate $\beta-\mathrm{TCP} /$ collagen covered with collagen membrane(Hypro-Sorb membrane) ${ }^{2}$.

\section{Pre-surgical preparation:}

Pre-surgical preparation was done through; Periodontal preparation and Radiographic preparation

\section{A-Periodontal preparation}

All patients were subjected to phase I periodontal therapy prior implant placement to provide an oral environment more favorable to wound healing.

\section{B-Radiographic preparation}

Cone Beam Computed Tomography were done for all patients.

\section{Surgical Procedure}

Each patient was asked to rinse her mouth with $0.2 \%$ chlorhexidine solution. After local anesthesia intrasulcular incisions were made to raise full thickness mucoperiosteal flap, the teeth were carefully removed by a traumatic extraction in order to protect and to preserve the alveolar bone. Sockets were curetted and irrigated with saline to remove granulation tissue and residual periodontal ligament. Sequential drilling with copious irrigation was carried out till the desired dimensions were achieved depending on the selected implant (Multi system-Italy) ${ }^{3}$. The selected implants were placed $2-3 \mathrm{~mm}$ beyond the apex to achieve primary stability. The cover screw was placed on the top the implant.

PRF membrane was prepared according to the protocol developed by Choukroun.

In group I patients: PRF membrane was used to cover (RTR) bone graft. (Fig1)

In group II patients: Hypro-Sorb was used to cover (RTR) bone graft.

The surgical wounds were sutured to achieve primary closure.

1. Septodont, Saint-Maur-des-Fosses, France

2. Bioimplon GmbH FriedrichList-Str. 27 Giessen. Germany

3. 20851 Lissone (MB) Italy Via General Guidoni, 7 
Post-operative instruction and medication were given for all patients

Sutures were removed 10-14 days after surgery.

\section{Patient evaluation}

\section{A. Clinical evaluation}

All patients were evaluated clinically using the following:

1. Implant stability

2. Peri implant probing depth

\section{B. Radiographic evaluation}

Cone beam computed tomography (CBCT) was done for all patients at baseline, 6and 12 month post operatively to evaluate:

1. Buccal bone plate thickness

2. Bone density

\section{Statistical analysis}

The data were collected, tabulated and statistically analyzed using IBM SPSS Statistics Version 20 for Windows.

\section{RESULTS}

\section{A. Clinical parameters (table 1)}

\section{Implant stability}

There was no statistically significant difference between (GroupI) and (Group II) in primary and secondary stability.

\section{Peri-Implant probing depth}

There was statistically significant difference between (Group I) and (Group II), at 6months only where $(\mathrm{p}=0.02)$.

\section{B. Radiographic parameters (table1)}

\section{Buccal bone plate thickness}

There were statistically significant differences between (Group I) and (Group II) at 6 months and 12 months where $(\mathrm{p}=0.02)$.

\section{Bone density}

There was statistically significant difference between (Group I) and (Group II), at 12 months only where $(\mathrm{p}=0.02)$.

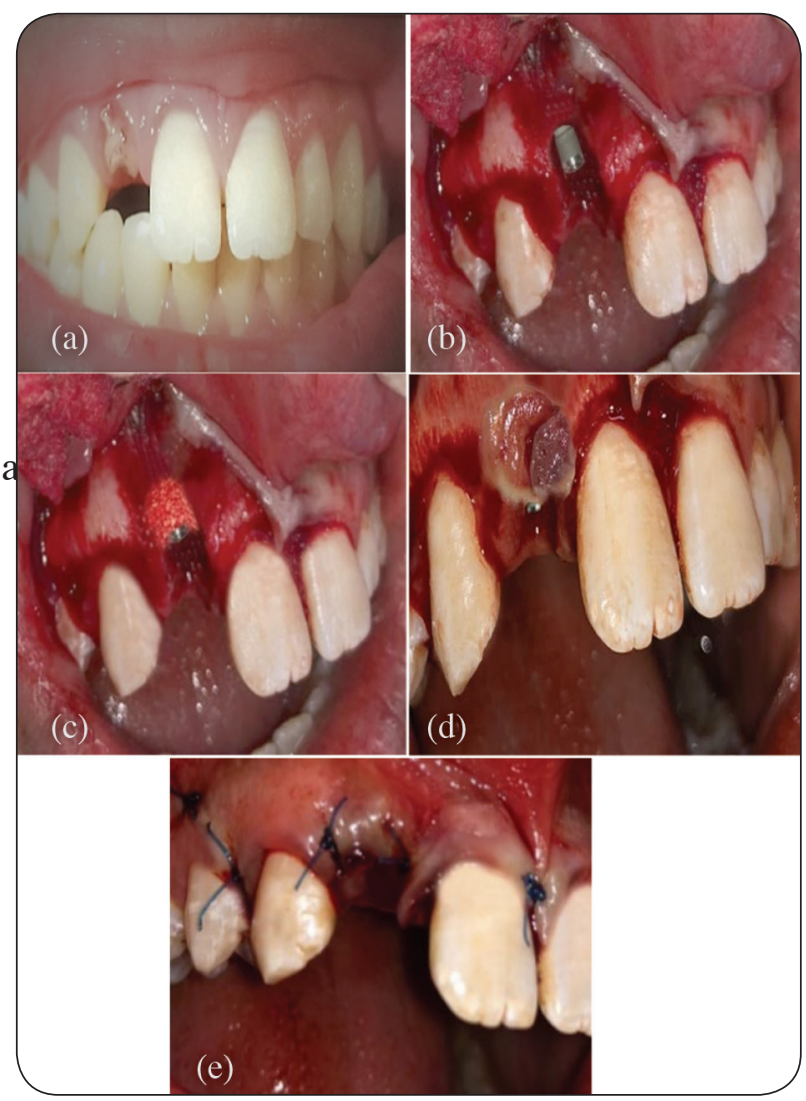

Fig. (1) a-e: Clinical photographs of group I patient

(a) Preoperative view. (b) After implant placement.

(c) $\beta-\mathrm{TCP} / \mathrm{col}$ graft filled the defect.

(d) Platelet-rich fibrin membrane placed over graft-filled defect.

(e) Post-operative view. 
Table (1) Showing clinical and radiographic results of the studied groups at different intervals including means \pm standard deviation as well as significance levels.

\begin{tabular}{|c|c|c|c|c|c|c|c|c|c|c|c|}
\hline & \multicolumn{5}{|c|}{ Clinical parameters } & \multicolumn{6}{|c|}{ Radiographic parameters } \\
\hline \multirow{2}{*}{ Variable } & \multicolumn{2}{|c|}{ Implant stability } & \multicolumn{3}{|c|}{ Peri-implant probing depth } & \multicolumn{3}{|c|}{ Buccal plate thickness } & \multicolumn{3}{|c|}{ Bone density } \\
\hline & Baseline & $6 \mathrm{~m}$ & baseline & $6 \mathrm{~m}$ & $12 \mathrm{~m}$ & baseline & $6 \mathrm{~m}$ & $12 \mathrm{~m}$ & Baseline & $6 \mathrm{~m}$ & $12 \mathrm{~m}$ \\
\hline \multirow{2}{*}{ G1 } & 62.30 & 75.5 & 3.65 & 2.60 & 2.50 & 0.98 & 2.84 & 2.60 & 478 & 496 & 500 \\
\hline & \pm 1.41 & \pm 2.56 & \pm 0.55 & \pm 0.48 & \pm 0.67 & \pm 0.16 & \pm 0.42 & \pm 0.19 & \pm 16.95 & \pm 15.13 & \pm 12.64 \\
\hline \multirow{2}{*}{$\mathrm{G} 2$} & 61.50 & 75.20 & 3.75 & 2.10 & 2.25 & 0.94 & 3.19 & 2.90 & 474 & 502 & 514 \\
\hline & \pm 1.52 & \pm 3.09 & \pm 0.51 & \pm 0.44 & \pm 0.40 & \pm 0.11 & \pm 0.16 & \pm 0.32 & \pm 13.69 & \pm 15.45 & \pm 13.65 \\
\hline$P$ value & 0.20 & 0.87 & 0.67 & $0.02^{*}$ & 0.23 & 0.59 & $0.01^{*}$ & $0.03^{*}$ & 0.60 & 0.39 & $0.02^{*}$ \\
\hline
\end{tabular}

\section{DISCUSSION}

Immediate implant placement is widely regarded as a reliable option to replace missing teeth, for function and esthetics. ${ }^{1}$

Dehiscence is considered as one of the major bony defects during implant placement, the presence of such defects decreases the bony support and may lead to gingival recession. ${ }^{14}$

The present clinical trial was designed to compare clinically and radiographically between Platelet Rich Fibrin (PRF) membrane and collagen membrane in combination with Beta tri calcium phosphate $\beta-\mathrm{TCP} /$ collagen in treatment of dehiscence around immediately placed dental implant.

The present study was used CBCT examinations in diagnosis, treatment plan as well as evaluation of treatment outcomes because CBCT can be considered a precise method for determining the buccal bone volume around dental implants as well as measuring the bone height between the implant platform and the first contact with bone at the buccal wall as mentioned by Shiratori et al (2012). ${ }^{15}$

The present study was used $\beta$-tri-calcium phosphate/col $(\beta-\mathrm{TCP} / \mathrm{col})$ as a bone substitute because it is a biocompatible and bioresorbable material with properties similar to the inorganic phase of bone and resulted in formation of newly formed bone as mentioned by Brkovic et al (2012) ${ }^{16}$ and to overcome some of disadvantages associated with the use of autogenous bone graft such as donor site morbidity, increased cost, potential resorption, size mismatch, and an inadequate volume of graft material.

In accordance to findings of systematic review and meta-analysis, GBR with particulate graft material and resorbable collagen membranes is an effective technique for lateral alveolar ridge augmentation prior to or simultaneously with dental implant placement, having similar implant survival rates compared to pristine bone, the present study was used collagen membrane with $\beta-\mathrm{TCP} / \mathrm{col}$ to treat dehiscence defect. ${ }^{11}$

In accordance to Dohan et al(2006) ${ }^{12}$ stated that PRF can serve as a resorbable membrane that can be used in preprosthetic surgery as well as in implantology to cover bone augmentation sites, the present study was used PRF membrane with $\beta$-TCP/ col to treat dehiscence defect.

No adverse reactions and no complications observed during the periods of the study. No implant failed up to 12 months after insertion, result in a $100 \%$ survival rate, no clinical mobility was detected in any of the implants throughout the follow up period. This was confirmed by radiographic evaluation that revealed absence of peri-implant radiolucency. 
This indicates success of implant in accordance to criteria of implant success reported by Karoussis et al (2004) $)^{17}$ and Misch et al (2008) $)^{18}$.

The results of the present study showed marked reduction in PPD at 6 and 9 months post-surgery this results agree with Hassan (2009) ${ }^{19}$ who evaluate the combination of autogenous bone graft and bioabsorbable polyglaycolic polylactic acid polymer versus autogenous bone graft alone in treatment of dehiscence around immediate implant and concluded that, the efficacy of guided bone regeneration in treatment of dehiscence around immediate implant.

Regarding to buccal bone plate thickness there was gain in buccal plate thickness from baseline to 12 months post-surgically in both groups.Sites treated with collagen membrane plus $\beta-\mathrm{TCP} /$ collagen show gain in buccal plate thickness from baseline to 12 months post-surgically was 0.94 and $2.90 \mathrm{~mm}$ compared with 0.98 and $2.60 \mathrm{~mm}$ in sites treated with PRF membrane plus $\beta$-TCP/collagen. This result agree with Sarnachiaro et al $(2015)^{20}$ they evaluate allograft and collagen membrane for treating buccal dehiscence with immediate implant placement, and found that the net gain in labial plate on cone beam computerized tomography (CBCT) was $3.0 \mathrm{~mm}$, where $0 \mathrm{~mm}$ existed at pretreatment.

\section{CONCLUSION}

Beta Tri Calcium Phosphate/Collagen combined with collagen membrane is significantly superior than Beta Tri Calcium Phosphate/Collagen combined with PRF membrane in treatment of buccal bone dehiscence during immediate implant placement.

\section{REFERENCES}

1. Al-Nawas B, Kammerer PW, Morbach T, Ladwein C, Wegener J\& Wagner W. Ten-year retrospective follow-up study of the TiOblast dental implant. Clin Implant Dent Relat Res 2012; 14:127-34.
2. Buser D, Janner SF, Wittneben JG, Brägger U, Ramseier C A \& Salvi G E. 10-Year survival and success rates of 511 titanium implants with a sandblasted and acid-etched surface: A retrospective study in 303 partially edentulous patients. Clin Implant Dent Relat Res 2012; 14:839-51.

3. Mayfield L. Immediate, delayed and late submerged and transmucosal implants In Proceedings of the 3rd European workshop on periodontology.Quintessence 1999;520-34

4. Cosyn J, De Lat L, Seyssens L, Doornewaard R, Deschepper E \&Vervaeke S. The effectiveness of immediate implant placement for single tooth replacement compared to delayed implant placement: A systematic review and meta-analysis J Clin Periodontol. 2019; 46: (Suppl. 21):224-41

5. Nevins M, Camelo M, De Paoli S, Friedland B, Schenk R K \& Parma-Benfenati S. A study of the fate of the buccal wall of extraction sockets of teeth with prominent roots. Int J Periodontics Restorative Dent 2006; 26:19-29.

6. Lustig J P,Tamse A \& Fuss Z. Pattern of bone resorption in vertically fractured,endodontically treated teeth. Oral Surg. Oral Med. Oral Pathol. Oral Radiol. Endod. 2000; 90(2):224-27.

7. Jung R E, Glauser R, Schärer P, Hämmerle C H, Sailer H F\& Weber F E. Effect of rhBMP-2 on guided bone regeneration in humans. Clin Oral Implants Res 2003; 14: (5) 556-68.

8. Rajan G, Fornaro J, Trentz O\& Zellweger R. Cancellous allograft versus autologous bone grafting for repair of comminuted distal radius fractures: A prospective randomized trial. J Trauma. 2006; 60:1322-29.

9. Mellonig J T. Autogenous and allogeneic bone grafts in periodontal therapy. Crit Rev Oral Biol Med 1992; 3:333-52.

10. Tadic D, Epple M. A thorough physicochemical characterization of 14 calcium phosphate-based bone substitution materials in comparison to natural bone. Biomaterials. 2004; 25: (6):987-94

11. Deshpande S, Deshmukh J, Deshpande S, Khatri R\& Deshpande S. Vertical and horizontal ridge augmentation in anterior maxilla using autograft, xenograft and titanium mesh with simultaneous placement of endosseous implants. J Indian Soc Periodontol.2014; 18: (5):661-5.

12. Bunyaratave $\mathbf{j} P \&$ Wang H-L. Collagen membranes: a review. J Periodontol. 2001; 72: (2):215-29. 
13. Dohan DM, Choukroun J, Diss A, Dohan SL, Dohan AJ\& Mouhyi J.et al Platelet-rich fibrin (PRF): a second-generationplatelet concentrate. Part III: leucocyte activation: a new feature for platelet concentrates? Oral Surg Oral Med Oral Pathol Oral Radiol Endod. 2006; 101:e51-55.

14. YANG Y. YANG H, PAN H, XU J\& HU T. Evaluation and new classification of alveolar bone dehiscences using cone-beam computed tomography in vivo. Int. J. Morphol. 2015; 33(1):361-68

15. Shiratori L N, Marotti J, Yamanouchi J, Chilvarquer I, Contin I \& Tortamano-Neto P. Measurement of buccal bone volume of dental implants by means of cone-beam computed tomography et al.. Clin Oral Implants Res 2012; 23:797-804.

16. Brkovic B M, Prasad H S, Rohrer M D, Konandreas G, Agrogiannis G\& Antunovic D et al. Beta-tricalcium phosphate/type I collagen cones with or without a barrier membrane in human extraction socket healing: Clinical, histologic, histomorphometric and immunohistochemical evaluation. Clin Oral Investig. 2012; 16:581-90.
17. Karoussis I K, Brägger U, Salvi G E, Bürgin W \& Lang N P. Effect of implant design on survival and success rates of titanium oral implants: a 10-year prospective cohort study of the ITIs Dental Implant System Clinical Oral Implants Research 2004; 15: (1):8-17

18. Misch C, Perel ML, Wang H, Sammartino G, GalindoMoreno P\& Trisi $\mathrm{P}$ et al. Implant success, survival and failure: International Congress of Oral Implantologists (ICOI) Pisa Consensus Conference. Implant Dent. 2008; 17(1):505-15.

19. Hassan K S. Autogenous bone graft combined with polylactic polyglycolic acid polymer for treatment of dehiscence around immediate dental implants. Oral Surg Oral Med Oral Pathol Oral Radiol Endod 2009; 108:e19-e25.

20. Sarnachiaro GO, Chu SJ, Sarnachiaro E, Gotta SL \& Tarnow D P Immediate Implant Placement into Extraction Sockets with Labial Plate Dehiscence Defects: A Clinical Case Series Clinical Implant Dentistry and Related Research,2015;18: 1-9 


\section{غشاء الاليفين الغني بالصفائح مقابل غشاء الكاء الكوالجين بالتزامن

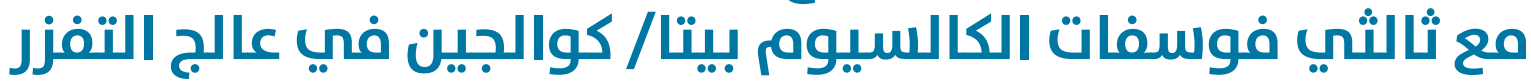

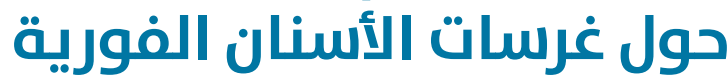 (دراسة مقارنة إكلينيكية وبالأشعة)}

\section{محمود أحمد ميزار * ، أحمد قاسه محمد ، خالد صديق حسان ، إبراهيم محمود موايِ} 1. قسـم طب الفم و أهراض اللثة ، والتشـخيص والاشعه , كلية طب الأسنان ، جامعة الازهر ، أسيوط ، جههورية

المواد والأسـاليب: أجريت هذه الدراسـة على عشـرين مريضا وقد تم تصنيف المرضى بشكل عشـوائي في مجسموعتين الجمهموعة الألولى: عشـرة

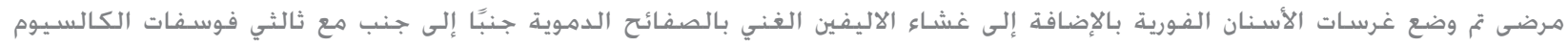

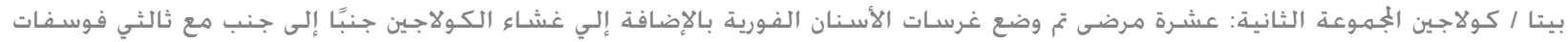

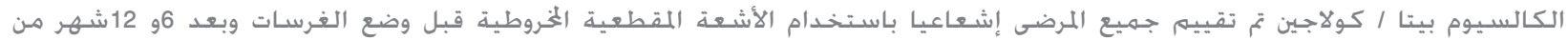
وضع الغرسات.

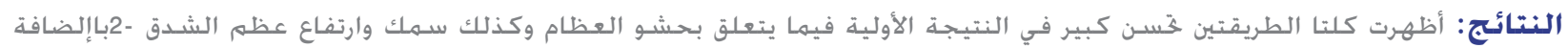

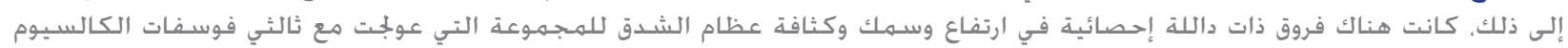

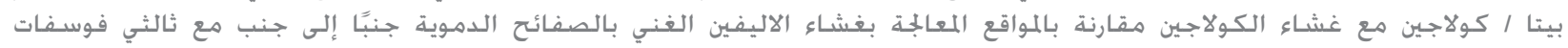
الكالسيوم بيتا / كولاجين

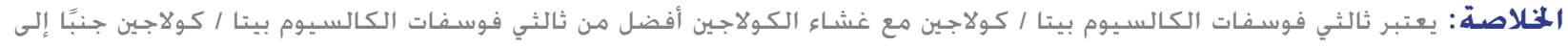
جنب مع غشاء الاليفين الغني بالصفائح الدموية في عالج تفزر عظم الشدق أثناء وضع الغرسات الفولاء الفرية. الكلمات المفتاحية: الاليفين الغني بالصفائح الدموية، وغشاء الكولاجين، ثالثي فوسفات الكالسيوم بيتا / كولاجين ، التفزر ، الغرسات الفورية. 